\title{
The Awareness of Green Products among Students
}

\author{
Shankar Chelliah, Wong Jun Hau, Lee Ming Huoy \\ Universiti Sains Malaysia
}

\begin{abstract}
In support for environmental concern and sustainable development, most countries are pay more attention to environmentally friendly consumption. Consumption of green has more intention among consumers and main impediment to both local and international marketers. As the green business is now becoming a trend and strategy, attention from Malaysian Government getting increase. In the recent years, the Malaysian Government has involved in numbers of green projects, green technology, promoting green business and encouraging a green consumerism among Malaysians. Each individual is responsible for environmental degradation which result harmful effect on environment. This study interested in investigating the influence of pro-environmental behavior, environmental knowledge \& concern and attitude towards green purchases on green purchase behavior among consumers, by focusing on students in Universiti Sains Malaysia (USM).
\end{abstract}

Keywords: Green Awareness, Sustainable, Green Products, Green Purchases

\section{INTRODUCTION}

In recent times, the environment has emerged as a hot issue for societies, governments, in addition to business organizations. By observing business organizations, such as; like sourcing, manufacturing, logistics, and marketing have negative impacts on the environment (Eltayeb, Zailani, \& Jayaraman, 2010). All through time, people's health, both on the individual and the community level have been affected through environmental problems.

Trend in green consumerism and green marketing are getting common in the west countries, but unfortunately Asian countries have just started to receive its appearance (Asia's Media and Marketing Newspaper, 2008). In reality, green marketing is the current big issues that help survival of business in a fast-changing world (Smith, 2009). "Going green" could present a firm with a three in one opportunity and creating a complete competitive advantage consists of low cost strategy, differentiation strategy and focusing strategy (Polonsky \& Rosenberger, 2001). Whilst, in consumers point of view, "going green" describes their actions such as increased use of renewal energy, planting grass and flowers in their home, or bringing own bags to the grocery store (Siegenthaler, 2010).

In this paper, will further investigate how environmental concern related to consumer purchase green product. By end of the study, able to bring in the correct define the crucial segment of the determination of green product combination in consumer community.

\section{Problem Statement}

Today, "green" is used most often to refer to new technology and new products bring sustainable and positive impact to the nature (Simula, Lehtimäki, \& Salo, 2009). Publications related to customers' environmental attitudes and influences on behavior concerned with the impact of company's "green" production, for example, environmentally conscious purchase decisions, energy saving consumption decisions or domestic recycling practices (Kalafatis, Pollard, East, \& Tsogas, 1999; Polonsky \& Rosenberger, 2001). In July 2008, The Boston Consulting Group conducted a global consumer survey to assess green attitudes and shopping behaviors and followed up with "pulse-check" surveys in Europe in October 2008 and in the United States in January 2009. The awareness of green product in Universiti Sains Malaysia (USM) still remain unknown. As representing of the behavior for colleague students.

\section{RESEARCH OBJECTIVE}

The objective of this research is to investigate factors that contribute in the awareness of green product among students' in USM. To obtain the result, variables with the effects will be measure. The research objectives as follows: 
1. To examine how green purchase intention impacts green purchase behavior.

2. To examine customers' determination of green purchase intention.

3. To examine the current state of students' awareness of green product.

\section{RESEARCH QUESTIONS}

This study is conducted to determine the relationship between competitive advantage and green product. Porter's competitive advantage theory has been adopted to determine factors that lead to green product (Porter, 1980). The factors as stated in his three generic strategies are cost leadership, differentiation and focus. Therefore, the research question to this study is as follows:

(a) What factors influences customers' green purchase behavior?

(b) How green awareness related to customer purchase green product?

(c) What is the relationship between focus strategy and green product?

\section{Significance OF STUdY}

In the past decade, words like green products, sustainable, environmentally friendly, eco-friendly and ecological have often been used interchangeably by companies to inform and lure the customers, by collect information from customers and understand view about customer's green purchase intention and frequency of purchasing green products. This research highlight factors that influenced customer to purchases green product help company to make appropriate change to improve its current state to help meet the demand and needs of each customer. Understanding environmental-friendly consumption behavior may enable companies to establish reputational and competitive advantages.

\section{Literature ReVIEWS}

\subsection{Green Product}

In general, green product is known as an ecological product or environmental friendly product. There are many definitions for it. Firstly, defined green product as the product that will not pollute the earth or deplore natural resources, and can be recycled or conserved (Shamdasani, Chon-Lin, \& Richmond, 1993). It is a product that has more environmentally sound content or packaging in reducing the environmental impact (Martin \& Simintiras, 1995). Another definition regarding to green product as product in which typically nontoxic, made from recycled materials, or minimally packaged (Ottman, 1998).

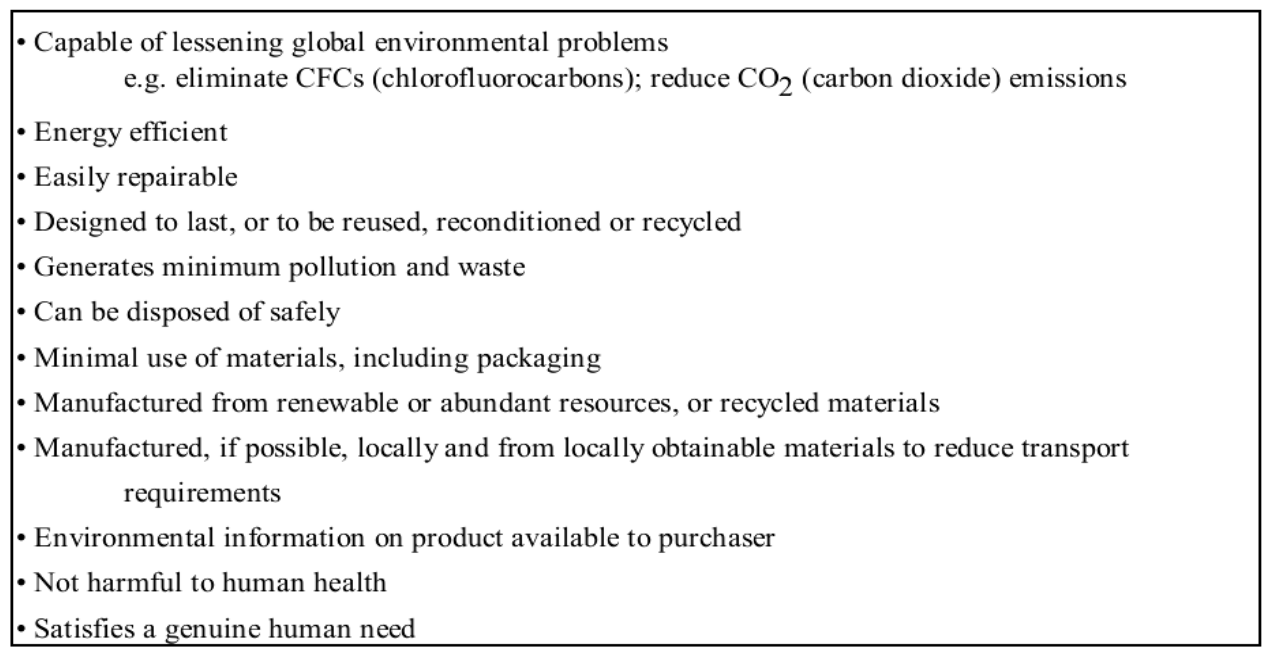

Figure1. Objective of Simmons for a green product,2011

\subsection{Green Product Strategies}

According to 'Capturing the Green Advantage for Consumer Companies' presented in January 2009, by the U.S. consultancy Boston Consulting Group (BCG), which advised companies on how to respond to consumer expectations regarding green issues and how to reach their business goals at the same time (Borin, Lindsey-Mullikin, \& Krishnan, 1992). The four dimensions are: Planning, Processes, Products, Promotion. 


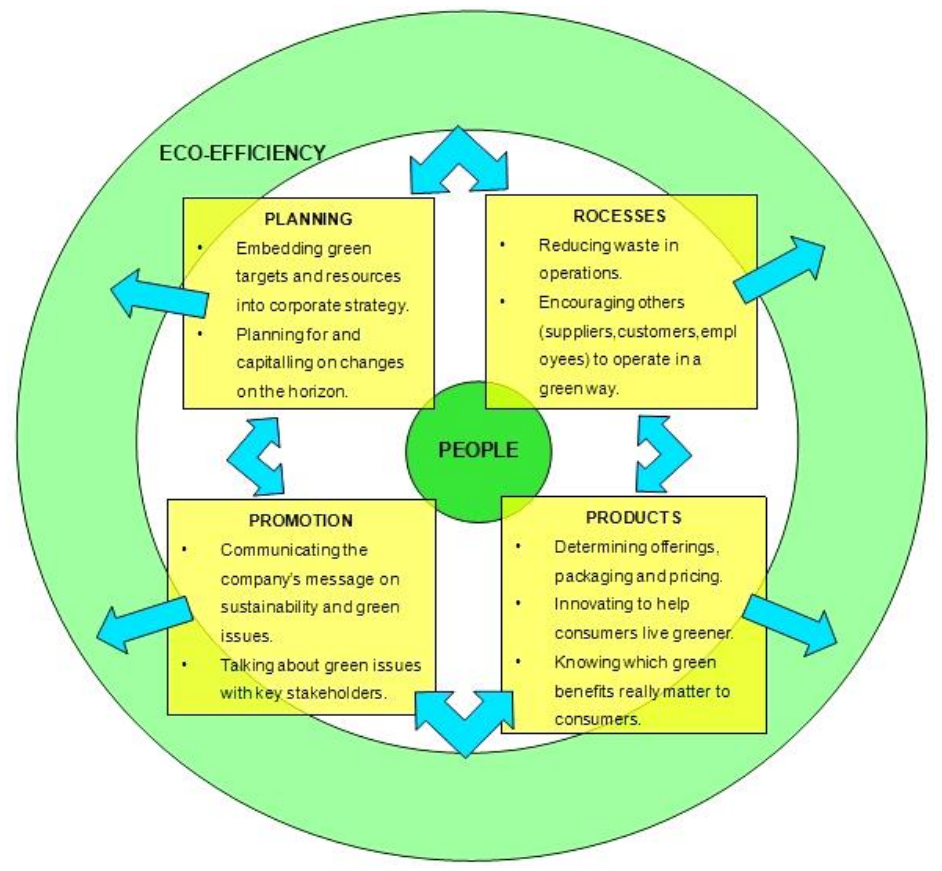

Figure2. The Green Strategy Mix

Therefore, stated that 'in a complex, holistic approach, the strategic mix can be enhanced' (Sima \& Gheorghe, 2009). The six dimensions of the green strategies of the companies shows in figure 2, known as The Green Strategy Mix (5P+EE). The six dimensions include: Planning Strategy; Processes Strategy; Product Strategy; Promotion Strategy; People Strategy; Eco-Efficiency Strategy.

Green marketing assume potential consumers will define 'green' product as an additional benefit and influence consumers purchasing decision. Increases of awareness towards green products, increases the demand of green products. Consumers became more sensitive to the environmental impacts of products and to their health, too, and this trend will certainly increase in the years to come (Sima \& Gheorghe, 2009).

\subsection{Product Competitive Advantage}

Competitive advantage is at the core of a firm's success or failure (Porter, 1996; Porter \& Victor, 1985), such advantage seeks to lead to control of the market and to larger-than-average profits. The importance of competitive advantage for firms has increased tremendously in the last decade. Of According to Porter (1985), management strategies for competitive advantage: Cost leadership strategy; Differentiation strategy; Niche strategy; Growth strategy; Alliance strategy; Innovation strategy; Operational effectiveness strategy; Customer-orientation strategy; Time strategy; Lock in customers or suppliers' strategy; Increase switching costs strategy (Porter \& Victor, 1985; Turban, King, Viehland, \& Lee, 2006).

Competitive advantages of a company as a condition under which competitors are unable to replicate its competitive strategies executed by the company, for are competitors able to acquire the benefit that the company obtains by means of its competitive strategies (Barney, 1991; Coyne, 1986; Porter, 1980). The measurement of competitive advantages of firms contained 11 items: (1) the company has the competitive advantage of low cost compared to its major competitors; (2) the quality of the products or services that the company offers is better than that of its major competitors' products or services; (3) the company is more capable of $R \& D$ and innovation than its major competitors; (4) the company has better managerial capabilities than its major competitors; (5) the company's profitability is better; (6) the growth of the company exceeds that of its major competitors; (7) the company is the first mover in some important fields and occupies some important positions; (8) the corporate image of the company is better than that of its major competitors; (9) the major competitors of the company cannot imitate its products or services easily; (10) the major competitors of the company cannot imitate its ideas easily; (11) the major competitors of the company cannot replace its distinctive position easily (Barney, 1991; Coyne, 1986; Porter, 1980). 


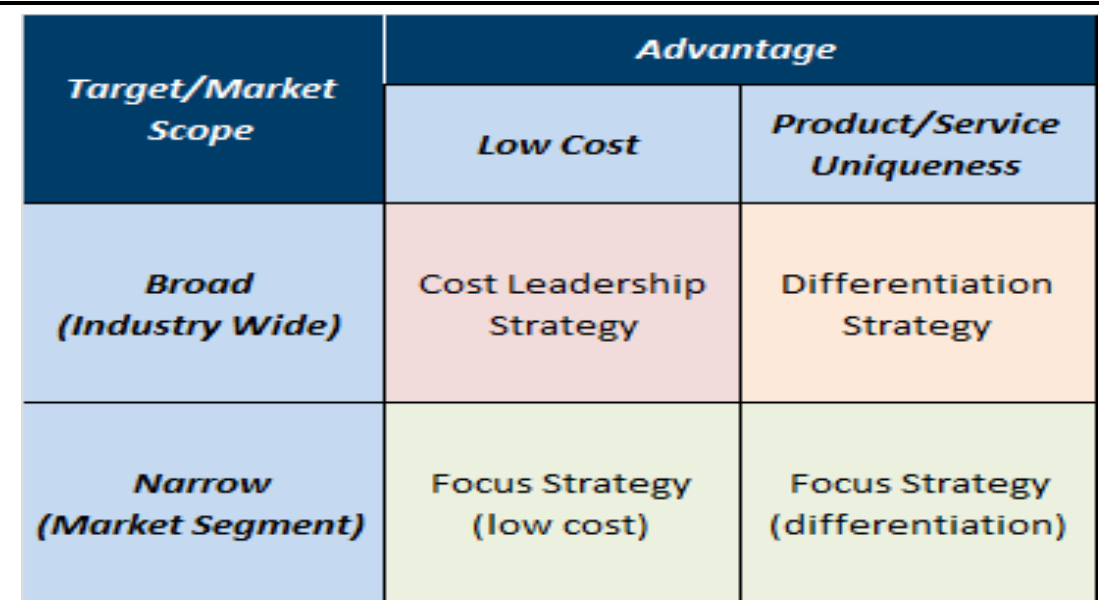

Figure3. Porter Competitive Advantage Model

Source: Porter, 1980

\subsection{Green Product Competitive Advantage}

Customers are ever more aware of the seriousness of environmental degradation, resulting more ecologically consciousness and desire to purchase eco-friendly products and services, favoring business that prefer environmental practice (Kalafatis et al., 1999; Laroche, Bergeron, \& BarbaroForleo, 2001; Roberts, 1996). 'Going green' could present a firm with a three in one opportunity and creating a complete competitive advantage consists of low cost strategy, differentiation strategy and focusing strategy based on Porter's view (Polonsky \& Rosenberger, 2001). Production and use entail less energy, less material input and less waste and pollution should be cost-effective for both consumer and companies.

\subsection{Pro-Environmental Behavior}

Pro-environmental behavior, also called green behavior. It is unlikely to deliver instant personal gain or gratification, but rather a future-oriented outcome (e.g. cleaner environment) that often benefits society as a whole (Kim \& Choi, 2005; McCarty \& Shrum, 2001). There is another research defined pro-environmental behavior, which is behavior that minimizes harm to the environment as much as possible, or even benefits it (Steg \& Vlek, 2009). Most simply, it has been described as 'doing good and avoiding bad' (Cushman-Roisin, 2012). Pro-environmental behavior often implies acting morally right, that is acting on considerations what is the right or wrong thing to do (Thøgersen, 1996), as it often does not benefit individual interests in the short term, but mainly benefits other people or the environment (Bagozzi \& Dabholkar, 1994; Thøgersen, 1996).

\subsection{Environmental Knowledge}

Environmental knowledge evolves in two forms; (1) consumers have to educated to be understand the impact of a product to environment; and (2) consumer knowledge in the product itself being produced in an environmentally friendly way. There are many ways on how consumers seeking for knowledge and evidences suggest that consumers are seeking knowledge by reading product label (D'Souza, Taghian, \& Lamb, 2006). Environmental Knowledge is defining as the knowledge on what people know about the environment, key relationships leading to environmental impacts, an appreciation of the whole systems, and collective responsibilities necessary for sustainable development (Mostafa, 2007).

Environmental knowledge as the sets of ecological knowledge that an individual has of environmental topics (Conraud-Koellner \& Rivas-Tovar, 2009). Both of these researcher's belief that environmental knowledge is influences by ecological ethnocentrism, degree of information, past behavior and perceptions about green products. On the other hand, define environmental knowledge as the amount of knowledge a person has regarding environmental issues (Chan \& Lau, 2000).

\subsection{Environmental Concern}

Concern of waste, wildlife, biosphere, responsibility, education, health and energy awareness to environmental technology are seven main dimension to be study under tropic related to environment concern. Study related to environmental knowledge, environment concern, ecological conscious 
consumer behavior and nature activities are the popular tropics for researchers in Malaysia (Mat Said, Ahmadun, Hj Paim, \& Masud, 2003). Environmental concerns can be a factor that influences consumer decision making process. Three dimensions of environmental concern were used to profiling green consumer, including knowledge about green issues, attitudes towards environmental quality and environmental sensitive behavior (Diamantopoulos, Schlegelmilch, Sinkovics, \& Bohlen, 2003).

\subsection{Attitudes Towards Green Purchases}

There are many definitions related to attitude but the most widely probably defines as mental and neural state of readiness, organized through experience, directive or dynamic influence upon the individual's response to all objects and situations (Greenwald, 1968). Similarity, define attitude as "an enduring organization of motivational, emotional, perceptual, and cognitive processes with respect to some aspect of the individual's world (Greenwald, 1968).

Attitudes towards environmental concern or awareness are fundamental concept of self and degree that individual perceives of the natural environment (Zelezny \& Schultz, 2000). As a summary, attitude able to represents consumers' feel toward like or dislike and consumers' product purchasing decisions often based consumers' environmental attitudes (Blackwell, Miniard, \& Engel, 2006).

Purchasing environmentally green products or friendly products, products with recyclable packaging or properly disposing of non-biodegradable garbage, consumers will perceive that able to contribute significantly to improve the quality of the environment (Abdul-Muhmin, 2007). Attitudes are the most consistent explanatory factor in predicting consumers' willingness to pay for green products, and price don't stop the purchase for green products (Chyong, Phang, Hasan, \& Buncha, 2006).

\subsection{Green Purchase Intention}

Behavioral intentions as a measure of a person's relative strength of purpose to execute certain behavior (Ng \& Paladino, 2009). Green purchase intention brings the meaning of probability and willingness of an individual to give preference to green product over conventional products in their purchase considerations. However, green purchase intention as a determination to act in a certain way (Ramayah, Lee, \& Mohamad, 2010).

\subsection{Green Purchase Behavior}

Green product can be categorized as a product that will not pollute the earth or deplore natural resources and can be recycled or conserved (Shamdasani et al., 1993). Some examples of these products are "household items manufactured with post-consumer plastics or paper, recyclable or reusable packaging, energy-efficient light bulbs and detergent containing ingredients that are biodegradable, non-polluting and free of synthetic dyes or perfumes" (Mostafa, 2007). Common terms normally used by companies promoting green products are "eco-friendly", "environmentally safe", "recyclable", "biodegradable" and "ozone friendly" (Qader \& Zainuddin, 2011). Pro-environmental behavior can be defined as the action of an individual or group that contributes to then sustainable use of natural resources (Chyong et al., 2006). It can be classified into green purchase behavior (Gupta \& Ogden, 2009; Kim \& Choi, 2005; Mostafa, 2007), energy saving, waste and recycling behavior (Barr, 2007) and participation in any nature-related activities (Haron, Paim, \& Yahaya, 2005).

Green purchase behavior refers to purchasing and consuming products that have minimal impacts on the environment (Abdul-Muhmin, 2007). There are different terms used interchangeably with green purchase behavior, such as green buying behavior (Kim \& Choi, 2005), pro-environmental purchase behavior and environmentally responsible purchase behavior (Tilikidou \& Delistavrou, 2005).

\subsection{Research framework and model development}

The conceptual model for this study was developed partly based on the Theory of Reasoned Action (TRA) model adopts Porter's (1985) and other variables from the extant literature in the area of green product purchasing. Two type of variables are consisted in the theoretical framework, independent variable and dependent variable. Below is the conceptual framework; 


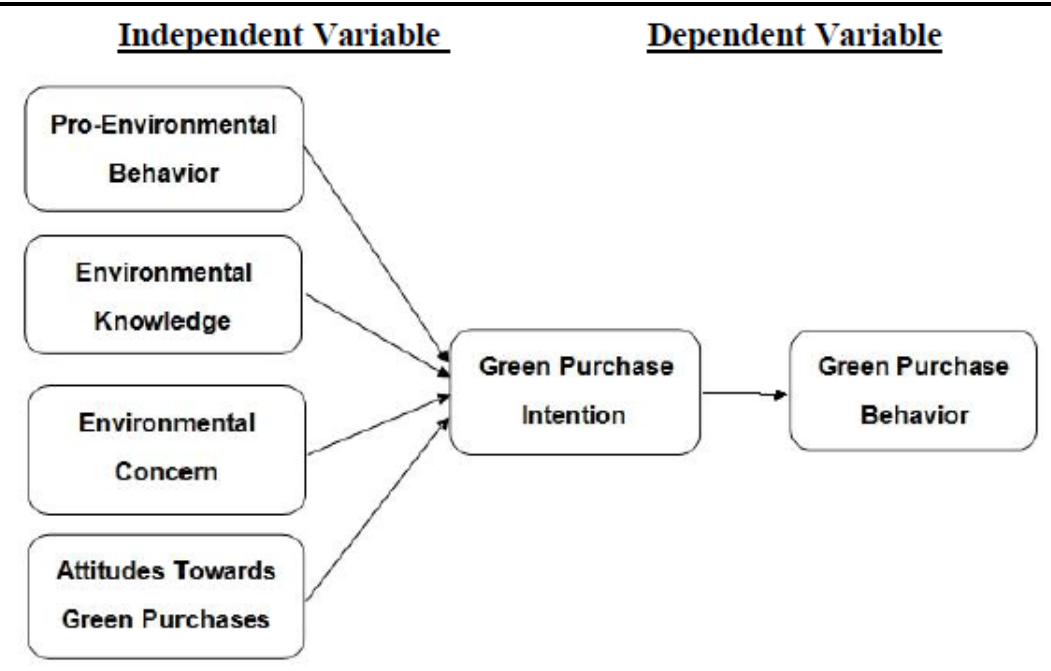

Figure5. Research Framework of Customers' Green Purchase Behavior

\section{Hypothesis}

Table1. Hypothesis

\begin{tabular}{|l|l|}
\hline $\mathrm{H}^{1}$ & Pro-environmental behavior is positively related to green purchase intention. \\
\hline $\mathrm{H}^{2}$ & Environmental knowledge is positively related to green purchase intention. \\
\hline $\mathrm{H}^{3}$ & Environmental concern is positively related to green purchase intention. \\
\hline $\mathrm{H}^{4}$ & Attitudes towards purchases green products is positively related with green purchase intention. \\
\hline $\mathrm{H}^{5}$ & Pro-environmental behavior is positively related to green purchase behavior. \\
\hline $\mathrm{H}^{6}$ & Environmental knowledge is positively related green purchase behavior. \\
\hline $\mathrm{H}^{7}$ & Environmental concern is positively related green purchase behavior. \\
\hline $\mathrm{H}^{8}$ & Attitudes towards green purchases is positively related green purchase behavior. \\
\hline $\mathrm{H}^{9}$ & $\begin{array}{l}\text { Pro-environmental behavior, environmental knowledge and concern, attitudes towards purchase green } \\
\text { products and green purchase intention are positively related green purchase behavior. }\end{array}$ \\
\hline
\end{tabular}

\section{RESEARCH METHODOLOGY}

\subsection{Population, Sample size and Sampling Technique}

The population is students who are studying in USM main campus in Penang. The general rule, minimum number of respondent or sample size is five-to-one ratio of the number of independent variables to be analyzed. The population is all students in USM Penang. However, sample in this research is the student in USM Penang who done our questionnaire. Randomly 120 students in USM Penang regardless their religion, gender, courses and so on.

\subsection{Scales and Measurement}

The interval scale of measurement was applied in Section 1 to Section 6. The attitude ratings are as follows:

Table2. Interval Scale of Measurement

\begin{tabular}{|l|l|}
\hline Strongly Disagree & 1 \\
\hline Disagree & 2 \\
\hline Neutral & 3 \\
\hline Agree & 4 \\
\hline Strong Agree & 5 \\
\hline
\end{tabular}

Table3. Measurement of Independent Variables and Dependent Variable (Yeoh \& Paladino, 2007)

\begin{tabular}{|c|c|c|c|}
\hline Section No. & Variable name & No. of Items & Source \\
\hline 1 & Pro-Environmental Behavior & 8 & BCG report 2009 \\
\hline 2 & Environmental Knowledge & 5 & Chan and Lau, 2000 \\
\hline 3 & Environmental Concern & 5 & Chan and Lau,2000 \\
\hline 4 & Attitudes Toward Green Purchases & 3 & Mostafa, 2007 \\
\hline 5 & Green Purchase Intention & 4 & Chan and Lau, 2000 \\
\hline 6 & Green Purchase Behavior & 5 & Yeoh and Paladino (2007) \\
\hline
\end{tabular}




\subsection{Statistical Data Analysis}

Various statistical methods were used to analyze the data that the researcher was collected from the respondents. Data collected were processed employing descriptive and inferential statistics via the Statistical Package for the Social Science (SPSS) Version 18.0, set at 0.05 significance level. In this study, the responses and information collected from the survey were tested using statistical techniques such as validity, reliability, descriptive, regression.

\subsection{Goodness and Correctness of Data Entry}

Establishing the goodness of data lends credibility to all subsequent analyses and findings (Sekaran, 2003). Purpose was to provide a preliminary idea of how good the scales were by checking the central tendency and distribution of the responses. Data will be checked against data entry error by running descriptive statistics for minimum, maximum, and count. The mean, range, standard deviation and variance in the data will give a good idea of how the respondents have reacted to items in the questionnaire (Sekaran, 2000). However, the missing value does not indicate whether the data had been entered correctly.

\subsection{Validity and Reliability}

Validity testing is very important to test the goodness of measures. To know the error that present in any measures, both validity and the reliability must be address. Validity is an extent to ensure the ability of a scale to measure the intended concept (Sekaran, 2003). Besides, Cronbach's coefficient alpha is a commonly used measure for internal consistency reliability. Cronbach's alpha value of .7 and above is considered to be reliable. An alpha value of .7 and above indicates items are homogenous and measuring the same construct. The alpha value of .5 would be deemed as low value of acceptability (Sekaran, 2003).

\section{ANALYSIS AND ReSUlt}

\subsection{Sample and Profile}

A total 120 respondents were completed the questionnaires in this survey. The mainly respondents in this survey are females which are $71(59.2 \%)$ of the respondents and $49(40.8 \%)$ of the 120 respondents are males. Besides that, it also shows that four aging group in this survey. It only has 4 (3.3\%) of the respondents are age under 20 years old. The mainly respondents are age 21-25 years old years old which are 68 (56.7) of the respondents. In addition, it also has 38 (31.7\%) of the respondents are age 26-30 years old and $10(8.3 \%)$ of the respondents are above 30 years old.

Based on our results in this survey, the most respondents are come from program undergraduate which 73 respondents $(60.8 \%)$ in education level. 36 respondents $(30 \%)$ are program masters and 11 respondents $(9.2 \%)$ are $\mathrm{PhD}$. The respondents comprised mainly of stream of study arts, 41 respondents $(34.2 \%)$ and 79 respondents $(65.8 \%)$ study Science stream. It also shows that 7 of the 120 respondents (5.8\%) study part time and 113 respondents (94.2\%) study full time. In addition, the most respondents are live in campus which is 39 respondents $(32.5 \%)$ of the 120 respondents and 81 $(67.5 \%)$ of the respondents live outside campus.

Further profiling $72.5 \%$ (87 respondents) of the respondents' result shows they often purchase green products, whereas $27.5 \%$ (33 respondents) are not. In the other hand, 94 respondents (78.3\%) agree it is beneficial to use green products, but another 26 respondents $(21.7 \%)$ disagree it is beneficial to use green products.

\subsection{Goodness of Measure}

\subsubsection{Reliability of Measure}

The first test carried out on the data was the reliability test on the multi-item instrumentals used in this research. The Cronbach's Alpha value was used to test the reliability of the items measuring each variable: Pro-Environmental Behavior (PEB), Environmental Knowledge (EK), Environmental Concern (EC), Attitude towards Green Purchase (AGP), Green Purchase Intention (GPI), Green Purchase Behavior (GPB). It is a reliability measure coefficient that reflects how good items in a set are positively correlated to one another. 
The results obtained indicate that the Cronbach's Alpha value for the measuring items of independent variables and dependent variables. The Cronbach's Alpha for attributive satisfaction was low at 0.670. The accepted base on the minimum Cronbach's alpha value is 0.50. All the items have alpha value that greater than 0.60. This clearly indicates that inter-consistency (Sekaran, 2003). From table 4, none of the items will delete in the test as the reliability of inter-item was high enough.

Table4. Summary of Reliability Analysis

\begin{tabular}{|l|l|l|l|}
\hline Variable & $\begin{array}{l}\text { Cronbach's } \\
\text { Alpha }\end{array}$ & $\begin{array}{l}\text { Number of item } \\
\text { deleted }\end{array}$ & $\begin{array}{l}\text { Total item } \\
\text { use }\end{array}$ \\
\hline Pro-Environmental Behavior (PEB) & 0.919 & - & 8 \\
\hline Environmental Knowledge (EK) & 0.844 & - & 5 \\
\hline Environmental Concern (EC) & 0.890 & - & 5 \\
\hline Attitude towards Green Purchase (AGP) & 0.878 & - & 3 \\
\hline Green Purchase Intention (GPI) & 0.837 & - & 4 \\
\hline Green Purchase Behavior (GPB) & 0.892 & - & 5 \\
\hline
\end{tabular}

\subsubsection{Descriptive Analysis}

The summary of the descriptive statistic of the variables is given in Table 5 and Appendix C. All variables are measured in 5-point Likert scale with increasing level of enjoyment with 5 being the strongly agree.

Table5. Overall Descriptive Statistics of the Study Variables

\begin{tabular}{|l|l|l|}
\hline Variable & Mean & Standard Deviation \\
\hline Pro-Environmental Behavior (PEB) & 3.8698 & 0.58190 \\
\hline Environmental Knowledge (EK) & 3.9150 & 0.55589 \\
\hline Environmental Concern (EC) & 4.0817 & 0.61603 \\
\hline Attitude towards Green Purchase (AGP) & 4.2000 & 0.62083 \\
\hline Green Purchase Intention (GPI) & 3.9875 & 0.62666 \\
\hline Green Purchase Behavior (GPB) & 3.9917 & 0.61978 \\
\hline
\end{tabular}

\subsection{Hypotheses Testing}

\subsubsection{Correlation Analysis}

The inter-correlations among all the study variables were investigated by Pearson Product-Moment Correlation. Table 6 and Appendix D provide the summary of the results.

Table6. Pearson's Correlation Coefficients of the Study Variables

\begin{tabular}{|l|l|l|l|l|l|l|}
\hline & $\boldsymbol{P E B}$ & $\boldsymbol{E K}$ & $\boldsymbol{E C}$ & $\boldsymbol{A G P}$ & $\boldsymbol{G P I}$ & $\boldsymbol{G P B}$ \\
\hline PEB & 1 & & & & & \\
\hline EK & $.788^{* *}$ & 1 & & & & \\
\hline EC & $.529^{* *}$ & $.518^{* *}$ & 1 & & & \\
\hline AGP & $.548^{* *}$ & $.634^{* *}$ & $.654^{* *}$ & 1 & & \\
\hline GPI & $.583^{* *}$ & $.607^{* *}$ & $.648^{* *}$ & $.669^{* *}$ & 1 & \\
\hline GPB & $.659^{* *}$ & $.643^{* *}$ & $.634^{* *}$ & $.693^{* *}$ & $.756^{* *}$ & 1 \\
\hline
\end{tabular}

**. Correlation is significant at the 0.01 level (2-tailed)

Table7. Summary for Hypothesis Testing

\begin{tabular}{|c|c|c|c|}
\hline Hypotheses & Description & Result & $\beta$ Value \\
\hline H1 & $\begin{array}{l}\text { Pro-environmental behavior is positively related } \\
\text { to green purchase intention. }\end{array}$ & $\begin{array}{l}\text { Rejected } \\
\text { Not } \\
\text { Significant }\end{array}$ & $\beta=0.143$ \\
\hline H2 & $\begin{array}{l}\text { Environmental knowledge is positively related to } \\
\text { green purchase intention. }\end{array}$ & $\begin{array}{l}\text { Rejected } \\
\text { Not } \\
\text { Significant }\end{array}$ & $\beta=0.150$ \\
\hline H3 & $\begin{array}{l}\text { Environmental concern is positively related to } \\
\text { green purchase intention. }\end{array}$ & Accepted & $\beta=0.298$ \\
\hline H4 & $\begin{array}{l}\text { Attitude towards green purchases is positively } \\
\text { related to green purchase intention. }\end{array}$ & Accepted & $\beta=0.301$ \\
\hline H5 & $\begin{array}{l}\text { Pro-Environmental Behavior is positively related } \\
\text { to green purchase behavior. }\end{array}$ & $\begin{array}{l}\text { Rejected } \\
\text { Not } \\
\text { Significant }\end{array}$ & $\beta=0.291$ \\
\hline
\end{tabular}




\begin{tabular}{|l|l|l|l|}
\hline \hline H6 & $\begin{array}{l}\text { Environmental knowledge is positively related to } \\
\text { green purchase behavior. }\end{array}$ & $\begin{array}{l}\text { Rejected } \\
\text { Not } \\
\text { Significant }\end{array}$ & $\beta=0.089$ \\
\hline H7 & $\begin{array}{l}\text { Environmental concern is positively related to } \\
\text { green purchase behavior. }\end{array}$ & $\begin{array}{l}\text { Rejected } \\
\text { Not } \\
\text { Significant }\end{array}$ & $\beta=0.213$ \\
\hline H9 & $\begin{array}{l}\text { Attitude towards green purchases is positively } \\
\text { related to green purchase behavior. }\end{array}$ & $\begin{array}{l}\text { Accepted } \\
\text { Pro-environmental behavior, environmental } \\
\text { knowledge, environmental concern, attitude } \\
\text { towards green purchases and green purchase } \\
\text { intention is positively related to green purchase } \\
\text { behavior. }\end{array}$ & Accepted \\
\hline
\end{tabular}

\section{Conclusion}

From the result, the multiple regression analysis of the this study, hypothesis 2 which predicts that there is significant relationship between environmental concern and green purchase intention, is supported and met the first assumption by Baron and Kenny (1986). The current finding indeed contradicts with the finding of involving Malaysians baby diapers users when their study found that environmental concern show insignificant effects on green purchase intention (Ramayah et al., 2010). A specific green product was used in study whilst this current study focused on a general green product (Ramayah et al., 2010). However, this finding is in line with demonstrated that there is a significant relationship exists between ecological concern and green purchase intention amongst their respondents (Chan \& Lau, 2000).

In the hypothesis test, results of $\mathrm{H}^{4}$ and $\mathrm{H}^{8}$ showed that the corresponding standardized regression coefficients for attitude in this study is significant of the variances in green purchase intention and green purchase behavior. Hence, these 2 hypotheses are supported. Attitudinal component was observed to be the most important predictor of green purchasing decision and also green purchase behavior (Schlegelmilch \& Crook, 1988). Meanwhile, reports that certain cultural, political and ethical factors are responsible for the adoption of an environmental attitude by consumers, whether when specifically making personal purchasing decisions (inward) or when broadly considering issues relating to society (outward) (Leonidou, Katsikeas, \& Coudounaris, 2010). An inward environmental attitude will stimulate green purchasing intention, then finally could enhance the purchase behavior of customer intend to green. In addition, an outward environmental attitude will lead to general proenvironmental actions.

In hypothesis test, $\mathrm{H} 1$ (pro-environmental behavior is positively related to green purchase intention) and H5 (pro-environmental behavior is positively related to green purchase behavior) are not significant and not supported, this means that although the life behavior of respondents tend to environmental friendly, and pro-environmental behavior fits well in their lifestyle, could improve their standard living, extend span of life and save the earth, but they also will not participate in purchase green.

In addition, H2 (Environmental knowledge is positively related to green purchase intention.) and H6 (Environmental knowledge is positively related to green purchase behavior.) are not significant and not supported as well. the results show that more than half respondents know well the knowledge about protection environment, but still will hesitant when they decide which product to buy, green or normal.

Lastly, from the result, $\mathrm{H} 9$ predicts that there is significant relationship between the relationship between customer's green purchase behavior and pro-environmental behavior environmental knowledge, environmental concern, attitude towards green purchases as well as green purchase intention.

Despite the level of mediation being different, this current finding concurs with in which they found that there was a full mediation effect by attitude towards environment on the relationship between green purchase intention and green purchase behavior (Yeoh \& Paladino, 2007). 


\section{IMPLICATIONS}

\section{Policy Implications}

The findings in the current study can be used by the policy makers to design a more effective policies and institutional actions to increase environmentally friendly behavior among Malaysian. Although the Malaysian Government has becoming more environmentally conscious and has taken an intensive initiative to become green country including constructing 15 years (10th, $11^{\text {th }}$ and12th Malaysia Plan) greening strategy, it is important to allocate more resources to achieve the goal in becoming green country. As suggested by the current study, attitude mediated the relationship between environmental concern and green purchase intention. Thus, proper educational programs and campaigns should start as early as kindergarten level to cultivate people awareness and positive green attitude among the citizens. The cultivated attitude may then flourish into the intention to buy green products.

\section{LIMITATION}

Firstly, due to time constraints and limited resources, the sampling frame for this study was only limited to university undergraduate, graduate and post graduate students as subject. Therefore, results must be used with caution. Consequently, the results of this study are not capable of generalization to all populations of consumers in Malaysia. By considering this very limitation, it is recommended that future research shall utilize broader demographic profile to analyze respondents. As young adults are not the only green consumers. There may be other age groups like middle agers and elderly people are also potential green consumers.

Secondly, the honesty of the respondents will influence the findings in this study. It is because individuals would agree more on socially desirable answers and disagree more towards socially undesirable answers. Sometimes, the respondents are just simply the questionnaire without a deep reading. This makes the result I get not accurate to reflect the real situation.

Finally, as this study only investigated on green products in general and I did not clearly that what are the green products we usually in our life.

\section{REFERENCES}

Abdul-Muhmin, A. G. (2007). Explaining Consumers' Willingness to Be Environmental Friendly. International Journal of Consumer Studies, 31(3), 237-247.

Ajzen, I. (1991). The Theory of Planned Behavior. Organizational Behaviour and Human Decision Processes, 50, 179-211.

Bagozzi, R. P., \& Dabholkar, P. A. (1994). Consumer Recycling Goals and Their Effect on Decisions to Recycle: A Means-End Chain Analysis. Psychology \& Marketing, 11, 313-340.

Barney, J. (1991). Firm Resources and Sustained compatitve Advantages. Journal of Management, Vol. 17(1), pg. 99-120.

Barr, S. (2007). Factors influencing environmental attitudes and behaviors: A UK case study of household waste management. Environment and Behavior, 39, 435-473.

Blackwell, R., Miniard, P., \& Engel, J. (2006). Consumer Behavior: Manson: Thompson.

Borin, N., Lindsey-Mullikin, J., \& Krishnan, R. (1992). An Analysis of Consumer Reactions to Green Strategies. Journal of Product \& Brand Management, 22(2), 118-128. doi: http://dx.doi.org/ $10.1108 / 10610421311320997$

Chan, R. Y. K., \& Lau, L. B. Y. (2000). Antercedents of Green Purchases: A Survey in China. Journal of Consumer Marketing, 17(4), 338-357.

Chyong, H. T., Phang, G., Hasan, H., \& Buncha, M. R. (2006). Going Green: A Study of Consumers' Willingness to Pay for Green Products in Kota Kinabalu. International Journal of Business and Society, 7(2), 40-54.

Conraud-Koellner, E., \& Rivas-Tovar, L. (2009). Study Of Green Behavior With A Focus On Mexican Individuals. iBusiness, 1, 124-131.

Coyne, K. P. (1986). Sustainable Competitive Advantage: What It Is, What It Isn't. Business Horizon, No. 29, 54-61.

D'Souza, C., Taghian, M., \& Lamb, P. (2006). An Empirical Study On The Influence Of Environmental Labels On Consumers. . Corporate Communications: An International Journal, 11(2), 162-173. 
Diamantopoulos, A., Schlegelmilch, B. B., Sinkovics, R. R., \& Bohlen, G. M. (2003). Can Sociodemographics Still Play a Role in Profiling Green Consumers? A Review of The Evidence and An Empirical Investigation. Journal of Business Research, 56, 465-480.

Eltayeb, T. K., Zailani, S., \& Jayaraman, K. (2010). The Examination on the Drivers for Green Purchasing Adoption among EMS 14001 Certified Companies in Malaysia. Journal of Manufacturing Technology Management, 21(2), 206-225.

Fishbein, M., \& Ajzen, I. (1975). Belief, Attitude, Intentions, and Behaviour: An Introduction of Theory and Research Reading, MA: Addison-Wesley.

Gotschi, E., Vogel, S., Lindenthal, T., \& Larcher, M. (2010). The Role of Knowledge, Social Norms, and Attitudes toward Organic Products and Shopping Behavior: Survey Results from High School Students in Vienna. The Journal of Environmental Education, 41(2), 88-100.

Greenwald, A. G. (1968). Cognitive Learning, Cognitive Response to Persuasion, and Attitude Change. Paper presented at the Academic Press INC., New York.

Gupta, S., \& Ogden, D. T. (2009). To Buy or Not To Buy? A Social Dilemma Perspective On Green Buying. Journal of Consumer Marketing, 26(6), 376-391.

Haron, S. A., Paim, L., \& Yahaya, N. (2005). Towards Sustainable Consumption: An Examination of Environmental Knowledge among Malaysians. International Journal of Consumers Studies, 29(5), 426-436.

Kalafatis, S. P., Pollard, M., East, R., \& Tsogas, M. H. (1999). Green Marketing and Ajzen's Theory of Planned Behaviour: A Cross-market Examination. Journal of Consumer Marketing, 16(5), 441-460.

Kim, Y., \& Choi, S. M. (2005). Antecedents of Green Purchase Behaviour: An Examination of Collectivism. Environment Concern and PCE. Advances in Consumer Research, 32, 592-599.

Laroche, M., Bergeron, J., \& Barbaro-Forleo, G. (2001). Targeting Consumers Who are Willing to pay more for Environmentally-Friendly Products. Journal of Consumer Marketing, 18(6), 503520.

Leonidou, L. C., Katsikeas, C. S., \& Coudounaris, D. N. (2010). Five Decades of Business Research into Exporting a Bibliographic Analysis Journal of International Management, 16(1), 78-91. doi:http://dx.doi.org/10.1016/j.intman.2009.06.001

Martin, B., \& Simintiras, A. C. (1995). The Impact of Green Product Lines on the Environment: Does What They Know affect How They Feel? Marketing Intelligence and Planning, 13(4), 16-23.

Mat Said, A., Ahmadun, F., Hj Paim, L., \& Masud, J. (2003). Environmental Concerns, Knowledge and Practices Gap Among Malaysian Teachers. International Journal of Sustainability in Higher Education, 4(4), 305-313.

McCarty, J. A., \& Shrum, L. J. (2001). The Influence of Individualism, Collectivism, and Locus of Control on Environmental Beliefs and Behavior. Journal of Public Policy and Marketing, 20(1), 93-104.

Mostafa, M. (2007). Gender Differences in Egyptian Consumers' Green Purchase Behaviour: The Effects of Environmental Knowledge, Concern and Attitude. International Journal of Consumer Studies, 31, 220-229. doi:http//dx.doi.org/10.1111/j.1470-6431.2006.00523.x

Ng, S., \& Paladino, A. (2009). Examining The Influences of Intention to Purchase Green Mobile Phones among Young Consumers: An Empirical Analysis. . ANZMAC, 1-8.

Ottman, J. A. (1998). Green Marketing: Opportunity for Innovation (2, illustrated, reprint ed.): NTC Business Books.

Polonsky, M. J., \& Rosenberger, P. J. (2001). Reevaluating Green Marketing: A Strategic Approach. Business Horizon, 22-30.

Porter, M. E. (1980). Competitive Advantages. New York: Free Press.

Porter, M. E. (1996). What is Strategy. Harvard Business Review, 74(6), 61-78.

Porter, M. E., \& Victor, A. M. (1985). How Information Gives You Competitive Advantage. Harvard Business Review, 63(4), 149-160.

Qader, I. K., \& Zainuddin, Y. (2011). The Impact of Media Exposure On Intention To Purchase Green Electronic Products Amongst Lecturers. International Journal of Business and Management, 6(3), 240-248. 
Ramayah, T., Lee, J. W., \& Mohamad, O. (2010). Green Product Purchase Intention: Some Insights From A Developing Country. Resources, Conservation and Recycling, 54, 1419-1427.

Roberts, J. A. (1996). Green consumers in the 1990s: profile and implications for advertising. Journal of Business Research, 36(3), 217-231.

Schlegelmilch, B. B., \& Crook, J. N. (1988). Firm-level Determinants of Export Intensity. Managerial and Decision Economics, Vol. 9(4), pg. 291-300.

Sekaran, U. (2000). Research Business Methods: A Skill Building Approach (3rd ed.). United States of America: John Wiley and Sons, Inc.

Sekaran, U. (2003). Research Methods for Business (4th ed.). Hoboken, NJ: John Wiley \& Sons.

Shamdasani, P., Chon-Lin, G., \& Richmond, D. (1993). Exploring Green Consumers in an Oriental Culture: Role of Personal and Marketing Mix. Advances in Consumer Research, 20, 488-493.

Siegenthaler, J. P. (2010). How Green Are Your Customers? . Supply House Times, 41-42.

Sima, V., \& Gheorghe, I. (2009, June 2009). The Green Dimension of Customer Satisfaction. Paper presented at the The 11th IBIMA Conferences, "Creating Global Economies through Innovation and Knowledge Management, Kuala Lumpur, Malaysia.

Simula, H., Lehtimäki, T., \& Salo, J. (2009). Managing Greenness in Technology Marketing. Journal of Systems and Information Technology, 11(4), 331-346. doi:http://dx.doi.org/10.1108/13287260 911002486

Steg, L., \& Vlek, C. (2009). Encouraging Pro-environmental Behaviour: An Integrative Review and Research Agenda. Journal of Environmental Psychology, 29, 309-317.

Thøgersen, J. (1996). Recycling and Morality A Critical Review of the Literature. Environment and Behavior, 28(4), 536-558.

Tilikidou, I., \& Delistavrou, A. (2005). Pro-environmental Purchasing Behavior: the Inhibiting Influence of the Materialistic Values. Paper presented at the Marketing Contributions to Prosperity and Peace, Proceedings of the 9th International Conference on Marketing and Development, Thessaloniki GR.

Turban, E., King, D., Viehland, D., \& Lee, J. (2006). Electronic Commerce 2006: A Managerial Perspective. Paper presented at the Prentice Hall, Upprt Saddle River, NJ.

Yeoh, M., \& Paladino, A. (2007). Analysing the Effects of Prestige on Environmental Attitudes and Behaviours upon Low-involvement Purchase s: Does Branding Matter? . Australian and New Zealand Marketing Academy (ANZMAC) Conference 2007, 2066-2074.

Zelezny, L. C., \& Schultz, P. W. (2000). Promoting Environmentalism. Journal of Social Issues, 56(3), 365-578 